\title{
Human rights and trafficking in women and children in India
}

\begin{abstract}
Trafficking in women and children is one of the most despicable forms of violations of human rights. Being a complex issue, it has been given short shrift from the academia, legal field and the civil society. It has often equated with prostitution but that is the half story. This paper is an attempt to present the trends and dimensions of trafficking from a human rights paradigm and demystify several issues surrounding it. It will also shed some light on the role of NGOs, the civil society and the family. The paper is based amply on the secondary literature and primary experiences. The human rights discourses is profoundly silent on this major issue which snatches away most of the human rights from the most vulnerable group. It has immense implications for future course as India is fast becoming a source, transit point as well as a destination for traffickers.
\end{abstract}

Keywords: trafficking, human rights, crime, prostitution, women and children
Volume I Issue 5 - 2017

\author{
Sanjoy Roy, Chandan Chaman \\ Department of Social Work, University of Delhi, India
}

Correspondence: Sanjoy Roy, Associate Professor, Department of Social Work, University of Delhi, India, Email sanjoyroy30@gmail.com

Received: April 05, 2017| Published: August 23, 2017

\section{Introduction}

The popular discourse of human rights shows it in poor light but the idea of human rights is much more beyond that. It has been asserted that human rights are standing on soft conceptual grounding and it has been just reduced to rhetoric. Many philosophers and legal theorists like Aristotle, Plato, Hume, Weber and Rawls who talked about natural justice, natural laws etc see the rhetoric as just loose talk and human rights with less intellectual strength and less strong teeth. It seems that human right activists seem more concerned with changing the world rather than interpreting it. The reluctance on the part of activists is understandable given the urgency to respond the terrible sufferings. But, despite all of this, society is unimaginable without the provision of rights. A right in its acute sense means the liberty to pursue one's own conception of good. It entails claim to those good needed for one's well-being as opposed to merely the liberty to engage in one's own pursuits. Hamid Ansari, ${ }^{1}$ vice-President of India has said in his speech 'Human Rights and Human Wrongs', that introspection is required on some issues of human rights. He further added that despite the presence of intellectual, legal and institutional framework of human rights, there have been continuous questions regarding the efficacy of it in actual implementation.

Trafficking in human beings involves the transportation, harbouring or receipt of persons by means of threat, coercion, abduction or fraud for the purpose of exploitation. The problem of human trafficking, particularly in women and children has emerged as grave social issue which is one of the most serious affronts to the dignity and human rights of them. It is a gross commercialization and commodification of innocent human lives. Though it is a borderless crime, India among many South-Asian countries is rapidly used as a source, transit point as well as destination for the traffickers. It is just not about the violation of human rights but it is the defeat of human rights. It is not only the human rights which are failing but the society and institutions are also to share the blame. In the context of increasing violence and deep-seated patriarchal values the traffickers' jobs becomes easy. Hence trafficking in women and children, which is the most vulnerable group, is the sordid tale of violation of human rights and dignity.

\section{Understanding human rights}

The concept of human rights has emerged from the concept of rights. There have been many western scholars with different sets of theory of rights like John Rawls (1921-2002) and Robert Nozick (1938-2003). In the liberal-individualistic theory of rights, Ronald Dworkin has given new insights. Dworkin in his work Taking Rights Seriously (1978) attempted to create a new theory of politics based on the adequacy of moral rights. Marx has regarded rights as a bourgeois concept and described at length that how rights are linked to politics and seems abstract. ${ }^{2}$ Louis Henkin observed rights as 'claims' rather than charity. ${ }^{4}$ All the debates and theory has generated the ground of human rights. Now let's move from the concept of rights to human rights.

Human rights have been understood as "basic moral guarantees that people in all countries and cultures possess simply because they are human'. Human rights are universal in nature. The moral doctrine of human rights aspires to recognise the fundamental prerequisites for each human being for a good life. This aspiration has been reflected in various declarations and legal conventions commencing with Universal Declaration of Human Rights (1948) followed by the European Convention on Human Rights (1954) and the International Covenant on Civil and Economic Rights (1966). These three documents constitute together the centrepiece of a moral doctrine of human rights. ${ }^{2}$ Jack Donnely has regarded human rights as the new standard of civilization. ${ }^{3}$ Hence, human rights are inalienable and inherent rights of humans. Let's now move to Indian context of human rights and its legality.

\section{Complexity of human rights}

$\mathrm{Baxi}^{4}$ has articulated at length what constitutes human rights. He says that there is no simple answer to a clear question: what are the rights of human beings. He further says that in defence and justification of human rights, we have produced "complex and contradictory discourses". Even the global consensus on human rights values serves as poor guides in translating idea into law or practice. In his book, The Future of Human Rights, $\mathrm{Baxi}^{4}$ has made us familiar with the complexity in the meaning of human rights and described 
human rights as: (a) ethical imperatives, (b) grammar of governance, (c) language of global governance, (d) insurrectionary praxis, (e) juridical production, (f) culture. It actually highlights the ambiguities in conceptualising and practicing human rights. But few scholars like Amartya $\mathrm{Sen}^{5}$ has tried to understand this dilemma and mentioned that "the framers of Universal Declaration in 1948 clearly hoped that the articulated recognition of human rights would serve as a kind of template for new laws" (p. 359). The emphasis should be on new legislation not just mechanical interpretation.

\section{Indian constitution and human rights}

The Indian constitution is in congruence with United Nations charter, Universal Declaration of Human Rights (UDHR) and several other international covenants as they all lay emphasis on human dignity. The constitution of India assures dignity of the individual which is a core value in its preamble. Even the constitution of India was drafted at the same time as the Universal Declaration of Human Rights and that is why, it has resonance of similar provisions. This becomes obvious when we look at Article-23 of the Part- III of the Indian constitution and articles 2-21 of Universal Declaration of Human Rights. The Part-IV of the Indian constitution which contains Directive Principles of state policy in the article 38, 39A, 41 etc. also has reflection of articles of 22-28 of the UDHR. So, it can be said that Indian constitution has enormous scope to protect and promote human rights and the Supreme Court of India has been at forefront to protect the human rights inherent in fundamental rights. The importance of fundamental rights can be imagined by that is not only available to citizens of India but also non-citizens and it establishes the relevance of rights in the times we are living.

\section{Human rights in the $2 I^{\text {st }}$ century}

Baxi $^{4}$ has mentioned that twentieth century of the Christina Era (latter half) is hailed as an age of human rights but what about twentyfirst century issues of human rights. It has been asserted that human rights discourses are much about civil and political rights which constitutes first generation of rights. Though first generations of rights are necessary prerequisite for a just society, but they do not reaches to the point of social justice. Hence, a shift towards second and third generation of rights is required (IGNOU, 2010). There is also a growing concern towards overhaul of the conception of human rights has proposed reconstruction of human rights towards the postmodern context.

\section{Understanding human trafficking}

According to Oxford dictionary, 'Trafficking' means deal in something especially illegally. It also offers new terms like drugs trafficking, arms trafficking and human trafficking. The conceptual meaning of human trafficking refers to "to the criminal practice of exploitation of human beings where they are treated as commodities for profit and after being trafficked, are subject to long term exploitation". ${ }^{6}$ Human trafficking (HT) has become one of the three most lucrative types of organised crimes, there are drugs and arms. This organised crime of human trafficking has reached 'a scary magnitude' because the extent of violations of human right is unbelievable and unimaginable. The sad part is that there is very little awareness of this crime among the masses. It is also because of its highly secret and clandestine nature. It has become such mind-boggling problem that it has become difficult to arrive at any consensual data as different agencies project different numbers. It has been termed as modern day slavery.

In 1949, the problem of trafficking got major attention when the UN adopted a Convention for the Suppression of the Traffic in Persons and the Exploitation of Prostitution which was the sole convention existed for fifty years. This convention was also criticised for being soft and not able to protect women. ${ }^{7}$ But a breakthrough achieved when the Global North feminist groups revived the antitrafficking movement. ${ }^{7,8}$ It was followed by creation of UN Special Reporter on violence against women in 1994 and a South Asian and Association for Regional Cooperation (SAARC) Convention on Prevention of trafficking in women and children for prostitution in 2002. ${ }^{7}$ The current international legal standard, which gives shapes to many domestic definitions is the Protocol to Prevent, Suppress and Punish Trafficking in Persons, Especially Women and Children, a protocol to the United Nations Conventions Against Transnational Organised Crime, commonly known as the Palermo Protocol (UN, 2000). The Palermo Protocol defines trafficking as: The recruitment, transportation, transfer, harbouring or receipt of persons by means of the threat or use of force or other forms of coercion, of abduction, of fraud, of deception, of the abuse of power or of a position of vulnerability or of the giving or receiving of payments or benefits to achieve the consent of a person having control over another person for the purpose of exploitation (UN 2000).

The Palermo Protocol (UN 2000) was the first point which defined trafficking from a wider perspective as a matter of international law. It took into account the pre-existing individual crimes such as abduction, kidnapping, forced prostitution and slavery. It highlighted three important areas and presented clarity on these:

A. It recognized that any human can be trafficked, not just women and children

B. HT is not just for sexual exploitation, it is for labour and other areas also.

C. It categorically mentioned that force, coercion or deception must be present.

D. The intent to exploit and control another human being is central to the crime of trafficking. So, the instance of defining and criminalizing trafficking as a specific crime validated the fact that, as to the level of egregiousness, the whole of trafficking in human beings is greater than sum of its parts (Bullard, 2008 , p. 114). It can be said that trafficking in human beings is specifically egregious crime as those who set out to do this exploit people during their most vulnerable times often in inconceivably inhuman ways.

The Protocol requires the states to:

A. Criminalize the trafficking in persons

B. Provide assistance and protection to victims in countries of origin, transit and destination

C. Provide assistance in the repatriation of victims

D. Have management on migration to prevent and detect trafficking

E. Have thrust on training, research and information to prevent trafficking 
F. India signed the protocol on December 2, 2002 and ratified recently on May 13, 2011. As a signatory to the protocol, India is bound to comply with the laws conforming to UNTOC and protocol's mandate.

\section{Phases of human trafficking}

There are three main phases of human trafficking which are origin; transit and destination point. Origin is the place from where the victims are recruited; transit denotes transportation and transfer, sometimes harbouring also. Destination is the final point where the victims are received and maintained for exploitation. Even the victims may be exploited in origin and transit phase but it is for a short period. At destination, negotiation takes place for maximum profits (Figure 1).

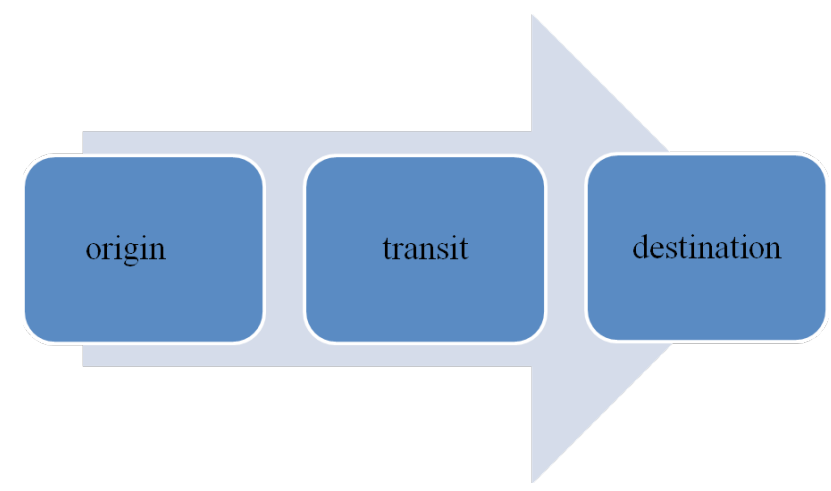

Figure I Phases of Human Trafficking.

\section{Problems in defining human trafficking}

Undoubtedly, the Palermo Protocol definition is an inclusive and objective. Even it moved a step further of earlier juxtaposition of trafficking with prostitution. But it has its critics. It has been expressed that this definition is more inclined towards crime-control and not included human rights in its ambit. ${ }^{6}$ The protocol is also criticized for being soft on the protection and restitution of victims. Also, Protocol's emphasis on sexual exploitation condoned the fact of trafficking for forced labour. ${ }^{7,9}$ There are also valid concerns that trafficking of women and children should be dealt separately to have a better understanding, not combined together. ${ }^{9}$ With changing social scenario, trafficking has become more organised and sophisticated and it requires a new articulation. Thus the debate is continuing and new definitions being suggested and adopted by several bodies in the trafficking fraternity. The other problem in defining is that as trafficking is a multi-dimensional problem and has various attributes and variables, a uniform definition will be elusive only. Hence there is no single definition upon which everyone agrees and a quest for all inclusive definition is on. Also, Palermo Protocol has recorded that trafficking is understood to take place only if three main constituents are present which process (transportation, recruitment etc.) are means (force and coercion); purpose (exploitation, labour or servitude).

\section{Trends and dimensions in human trafficking}

Possibly most country in the world and most state of our country are grappling with the issue of human trafficking as their geographical areas become places of origin, transit or destination of victims. Trafficking of persons has been termed as modern day slavery as it encircles the life and dignity of the victims. In this context, former UN Secretary- General has mentioned that slavery was actually the first international violation of human rights. Humans are trafficked for various purposes such as commercial sexual exploitation, slavery, for organs, forced marriages, labour and adoption. Human trafficking is not occasional crime but it is rampant and affecting every state of the country. It not only crosses national and international level but has street level occurrence also. The victim of the trafficking can be an acquaintance and trafficker can also be a familiar person. India in a continued seventh time remained on the Tier 2 watch list and in the Trafficking in Persons (TIP) report 2014, which is issued by the US state department annually, received lowest rank.

\section{Trends in India}

According to National Crime Records Bureau (NCRB), 2013 report, there is an increase of $10.9 \%$ in human trafficking reported incidence (3,940 cases in 2013 as compared to 3,554 cases in 2012). There is a trend of increasing reported cases of human trafficking. From 2,848 cases relating to human trafficking reported during 2009 , it rose to 3,422 cases in 2010. It further rose to 3,517 cases in 2011, 3,554 cases in 2012 and 3,940 cases in 2013 (Table 1).

Table I Incidence of human trafficking during 2009-20I 3

\begin{tabular}{ll}
\hline Year & Number of reported cases \\
\hline 2009 & 2848 \\
2010 & 3422 \\
2011 & 3517 \\
2012 & 3544 \\
2013 & 3940 \\
\hline
\end{tabular}

Source, NCRB, 2103

The crime of human trafficking during the year 2013 has increased by 38.3 per cent over 2009. It is just the number of reported cases, leave alone the unreported cases. As the human trafficking is highly clandestine in modus operandi, the major number of cases never comes into public domain.

The NCRB has been collecting data under the following heads of crime which are related to human trafficking:

A. Procurement of minor girls (Section 366-A IPC).

B. Importation of girls from foreign country (Section 366-B IPC).

C. Selling of girls for prostitution (Section 372- IPC).

D. Buying of girls for prostitution (Section 373- IPC).

The crime head-wise details of reported crimes during 2009 to 2013 along with percentage variation in the year 2013 over 2012 are presented in the Table 2.

If we look at the procurement of minor girls, a total of 1,224 cases were reported in the year 2013 as compared to 809 such cases in 2012, showing an increase of 51.3percent over 2012. During the last four years, a mixed trend can be observed. When it comes to import of minor girls from foreign country, there are 31 cases reported in 2013 as compared to 59 cases reported in the previous year. Here, we find decline of 47.5 per cent in reported cases. Both selling and buying of girls for prostitution has seen decline in 2103 than previous year. But there is very marginal decline in selling of girls which is only 7.4 per cent but buying of girls has witnessed a major decline standing at 60 
per cent. As far as the Immoral Traffic Act is concerned, there is a very marginal growth in the registration of cases in the 2103. So, overall this is the mixed trend of incidence of various crimes under human trafficking. It will be better if we look at the crimes registered in the various states because it will give us the idea and trends across states apart from the analysis of year-wise cases (Table 3).

Table 2 Crime head-wise incidence of various crimes under human trafficking during 2009-2013 and percentage variation in 2013 over 2012

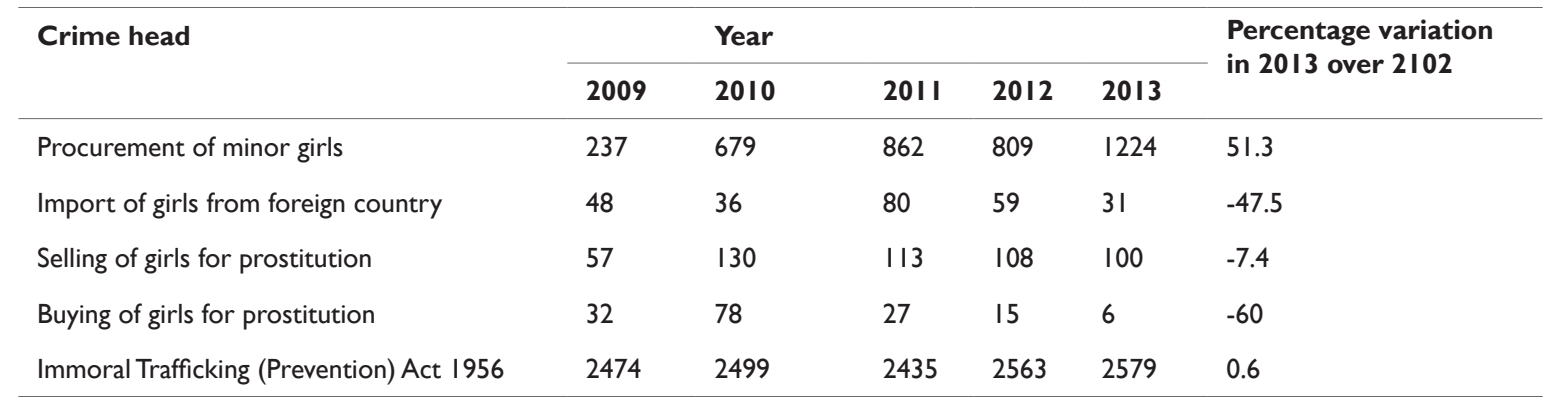

Source, NCRB, 2013

Table 3 Cases registered under human trafficking during 2013

\begin{tabular}{|c|c|c|c|c|c|c|}
\hline State/ut & $\begin{array}{l}\text { Buying of girls for } \\
\text { prostitution }\end{array}$ & $\begin{array}{l}\text { Selling of girls } \\
\text { for prostitution }\end{array}$ & $\begin{array}{l}\text { Procurement } \\
\text { of girls }\end{array}$ & $\begin{array}{l}\text { Import } \\
\text { of girls }\end{array}$ & $\begin{array}{l}\text { Immoral trafficking } \\
\text { (Prevention) act, } 1956\end{array}$ & Total \\
\hline Andhra Pradesh & 0 & 2 & 40 & 0 & 489 & 531 \\
\hline Arunachal Pradesh & 0 & 0 & 0 & 0 & 2 & 2 \\
\hline Assam & 0 & 0 & 129 & 2 & 18 & 149 \\
\hline Bihar & 0 & 3 & 193 & 7 & 64 & 267 \\
\hline Chhattisgarh & 0 & 0 & 44 & 1 & 8 & 53 \\
\hline Goa & 0 & 0 & 0 & 0 & 28 & 28 \\
\hline Gujarat & 0 & 2 & 0 & 0 & 76 & 78 \\
\hline Haryana & 0 & 2 & 0 & 2 & 63 & 67 \\
\hline Himachal Pradesh & 0 & 0 & 1 & 0 & 4 & 5 \\
\hline Jammu \& Kashmir & 0 & 0 & 1 & 0 & 1 & 2 \\
\hline Jharkhand & 2 & 5 & 17 & 2 & 11 & 37 \\
\hline Karnataka & 0 & 1 & 71 & 0 & 340 & 412 \\
\hline Kerala & 0 & 0 & 15 & 0 & 180 & 195 \\
\hline Madhya Pradesh & 0 & 3 & 21 & 7 & 22 & 53 \\
\hline Maharashtra & 2 & 31 & 41 & 0 & 289 & 345 \\
\hline Manipur & 0 & 0 & 22 & 0 & 0 & 22 \\
\hline Meghalaya & 0 & 0 & 8 & 0 & 4 & 12 \\
\hline Mizoram & 0 & 0 & 0 & 0 & 0 & 0 \\
\hline Nagaland & 0 & 0 & 0 & 0 & I & 1 \\
\hline Odisha & 0 & 0 & 79 & 0 & 27 & 106 \\
\hline Punjab & 0 & 0 & 1 & 0 & 137 & 138 \\
\hline Rajasthan & I & 0 & 54 & 1 & 74 & 130 \\
\hline Sikkim & 0 & 0 & 0 & 0 & 0 & 0 \\
\hline Tamil Nadu & 0 & 0 & 0 & 0 & 549 & 549 \\
\hline Tripura & 0 & 0 & 0 & 0 & 0 & 0 \\
\hline Uttar Pradesh & 0 & 0 & 0 & 0 & 37 & 37 \\
\hline
\end{tabular}


Table Continued....

\begin{tabular}{|c|c|c|c|c|c|c|}
\hline State/ut & $\begin{array}{l}\text { Buying of girls for } \\
\text { prostitution }\end{array}$ & $\begin{array}{l}\text { Selling of girls } \\
\text { for prostitution }\end{array}$ & $\begin{array}{l}\text { Procurement } \\
\text { of girls }\end{array}$ & $\begin{array}{l}\text { Import } \\
\text { of girls }\end{array}$ & $\begin{array}{l}\text { Immoral trafficking } \\
\text { (Prevention) act, I956 }\end{array}$ & Total \\
\hline Uttarakhand & 0 & 0 & I & 0 & 13 & 14 \\
\hline West Bengal & 1 & 69 & 486 & 9 & 104 & 669 \\
\hline Total (states) & 6 & 100 & 1224 & 31 & 2541 & 3902 \\
\hline A \&N Islands & 0 & 0 & 0 & 0 & 4 & 4 \\
\hline Chandigarh & 0 & 0 & 0 & 0 & 6 & 6 \\
\hline D\& N Haveli & 0 & 0 & 0 & 0 & 2 & 2 \\
\hline Daman\& Diu & 0 & 0 & 0 & 0 & 6 & 6 \\
\hline Delhi & 0 & 0 & 0 & 0 & 20 & 20 \\
\hline Lakshadweep & 0 & 0 & 0 & 0 & 0 & 0 \\
\hline Puducherry & 0 & 0 & 0 & 0 & 0 & 0 \\
\hline Total (UTs) & 0 & 0 & 0 & 0 & 38 & 38 \\
\hline Total (India) & 6 & 100 & 1224 & 31 & 2579 & 3940 \\
\hline
\end{tabular}

Source, NCRB, 2013

In buying of girls for prostitution, there were 6 cases registered in the country during the year 2103 . Though there was overall decrease in the number of cases from the previous year (2012), Jharkhand and Maharashtra together accounted for 66.7 per cent reported cases in 2013. In the case of selling of girls for prostitution, 100 cases were reported in the country during 2013 against 108 such cases in 2012, thus indicating a decrease of $7.4 \%$ over 2012. West Bengal has accounted for $69.0 \%$ (69 cases out of 100 cases) of the total cases of selling of girls for prostitution reported in the country. In the case of import of girls, a decline of $47.5 \%$ has been observed as 31 cases were reported during the year 2013 as compared to 59 cases in the previous year (2012). West Bengal (9 cases), Bihar and Madhya Pradesh (7 cases each) together accounting for nearly two-third $(74.2 \%)$ of total such cases at the national level. When it comes to procurement of girls, a total of 1,224 cases were reported in the year 2013 as compared to 809 such cases in 2012, showing an increase of $51.3 \%$ over 2012. West Bengal has reported 486 such cases indicating a share of $39.7 \%$ at the national level followed by Bihar (193 cases) $(15.8 \%)$ and Assam (129 cases) (10.5\%). A mixed trend was observed in these cases during the last four years.

\section{Dimensions of human trafficking}

Human trafficking is a multi-dimensional problem. There is not only significant rise in trafficking but also increase in its magnitude. The literature on trafficking carries conflicting layers of understanding with trafficking equated with prostitution and migration. Any reliable statistical information is absent in terms of quantification of almost any aspect of trafficking, from the number of people trafficked to the amount of money earned but it is estimated by UNICEF that it is around 5 to 10 billion dollars earned per year by traffickers. ${ }^{10}$ The United Nations estimated the number of trafficking victims at more than 30 million, with the largest number originating in Asia and an estimated 1, 50, 000 annually in South Asia alone. ${ }^{9}$ The Indian government's Ministry of Women and Child Development estimated the number of persons trafficked for commercial sexual exploitation in India to be around 2.8 billion and about three million prostitutes in the country. It is said to be 'acquiring grave dimensions worldwide in the recent context of globalisation'. ${ }^{6}$ Also, there is rise in the 'global sophistication, complexity and consolidation of trafficking networks' which is said to having diverse and sophisticated mechanisms. ${ }^{6}$

According to 'Report on Trafficking in Women and Children India' by Sen and Nair, ${ }^{6}$ the overall major trends are:

A. Trafficking major purpose is commercial sexual exploitation

B. There is a repeated preference for younger children and inclusion of men.

C. Trafficking is becoming extremely lucrative business, sometimes exceedingly doing well than arms and drug trafficking.

D. There is strong nexus between traffickers and public officials with the participation of corporate, sex and tourism industry.

E. Majority of women and children are trafficked through deception and false promises

All these trends are enormously prevalent in India as well as in the global context. Let us now move to analyse the factors which contribute in the above mentioned trends and also discuss other aspects which coalesced and contribute to these trends. According to Ghosh ${ }^{11}$ human trafficking in India can be classified into three groups: (a) for commercial sexual exploitation, (b) for exploitative labour and (c) for other forms of exploitation like organ sale, begging, etc. A quick analysis of the available records and reports on trafficking reveals that the trafficked women and children are pressed into activities like prostitution in brothels, massage parlours or beer bars, pornography, dancing, petty crimes, domestic help, agricultural labour, begging organ trade and drug trafficking.

\section{Factors contributing to trafficking}

There seems to be many factors at play in trafficking ranging from personal circumstances to structural factors. It has been articulated that traffickers originate where the conditions are ripe for exploitation. Sometimes there are social pressures on the victims to 
migrate, sometimes lack of employment or educational opportunities, sometimes unstable family structure also play a role. Traffickers are becoming smarter as they know how to target both the most vulnerable and the least visible people.

\section{Personal circumstances and structural factors}

In terms of personal factors, people with low levels of literacy, awareness and information are seemingly vulnerable to trafficking. Economic deprivation and low incomes are also contributing risk factors. Women and children with disabilities are an easy catch for traffickers. A dysfunctional family- fragile relationships, marital discord, physical abuse, sexual abuse, drug use, family pressures, gender discrimination, desertion by husbands- makes women vulnerable to suffering and consequently to trafficking. Studies by CSWB and others have revealed that most trafficked women are unmarried, divorced, separated or widowed. ${ }^{6}$ When we look at the structural factors, there are lot of aspect which makes women and children susceptible to trafficking. The environments which do not have adequate structures and institutions for education and employment become zones for traffickers. The wider structural factors also heavily influences and determine these circumstances which are industrialisations and globalisations, economic crises, under-development, economic policies like privatisation and liberalisation, promotion of sex tourism, withdrawal of subsidies and commercialisation of agriculture, the consequent erosion of subsistence agricultural practices, loss of traditional livelihoods and inflation. In today's scenario, women and girls are increasingly being hired as service providers which put them at risk. Simultaneously, the quickening pace of urbanisation and heightened mobility resulting from the development of road links are contributing factors. A culture of consumerism, materialism, commodification of individuals and commercialisation of sex distorts family needs and individual desires. ${ }^{6}$

\section{Perpetuating factors}

Insufficient and inadequate laws, poor enforcement, ineffective penalties, minimal chances of prosecution, the relatively low risks involved, corruption and complacency, poor visibility and less debate on the issue, the lack of political will of the governments to implement policies and to provide adequate services for victims- all play role in perpetuating trafficking. It has been also expressed that people who takes up the cudgels against trafficking are in miniscule. It becomes difficult to combat because everyone (trafficking camp) is unified. The profiting families are also reluctant to talk. ${ }^{12}$

\section{Push and pull factors}

Veerendra Mishra $^{13}$ has mentioned in his edited book that trafficking is victims' vulnerability exploitation and the victim vulnerability is result of many factors. He has classified those factors as push and pull factor and maintains that push and pull factors are not only determines vulnerability but they operate with multiple factors with different intensity. So, it becomes difficult to find out which factor has triggered the trafficking. His push and pull is similar to above mentioned personal and perpetual factors. Let's understand this through Figure 2.

Push factors are the factors which exist at the point of origin and the pull factors works at the place of destination. Pull factors has been considered the vices of uneven development. Both these factors are complementary. Push factors can minimized while pull factors cannot be stopped for the time being. Mishra ${ }^{13}$ has suggested that push factors are deep rooted problems which can be changed by continuo's education and not by confrontation approach. Both these factors have been described by some as 'supply' and 'demand' theory where pull factors have been equated with demand and push factors with supply. Let's now discuss the aspects of push and pull factors briefly.

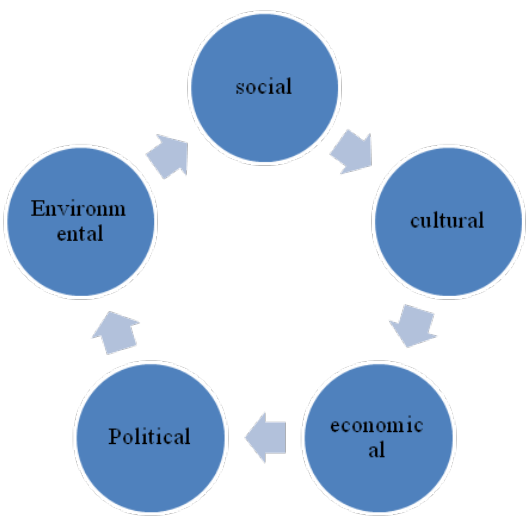

Figure 2 Push Factors.

In the push factors, social means prevalence of caste and class structure and gender based discrimination which makes people vulnerable. In cultural context, irrational traditional practices like community-based prostitution enhance the vulnerability. Economic factors means unequal distribution of opportunities and wider gap between rich and poor compels people to fell into the hands of traffickers. Poverty has been linked with human trafficking patterns. Political means unequal participation in the community at large while environmental suggests that natural calamities like floods, famines and drought or unnatural ethnic conflicts and insurgencies makes the people vulnerable for trafficking. Also, displacement and dislocation of people make situation favourable for traffickers (Figure 3).

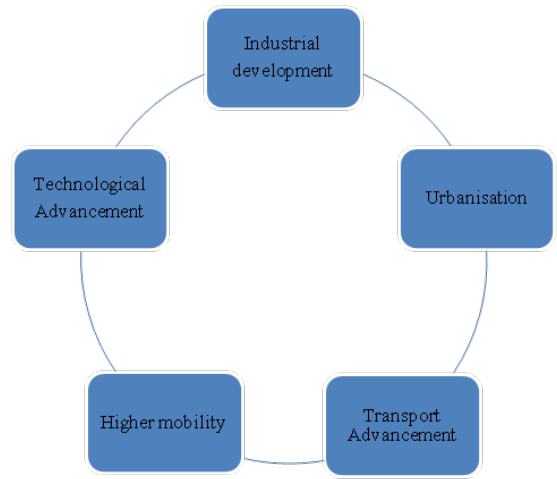

Figure 3 Constituents of Pull Factors.

\section{Modus operandi of human trafficking}

The articulation on the modus operandi of the trafficking is based on the analysis of the secondary literature and several field experiences. There seems to be impenetrable organisation and functioning of trafficking. If we look at the process of trafficking, it consists of few stages. In the first stage, the victims are recruited from a village or a city and in the second stage they are transported to a designated location/transit point. In the third stage, in some cases which is final also, the victims are shifted to a central position. After that they are 
moved to final destination. In several cases, the victims are moved to and fro before shifted to final destination. ${ }^{6,9}$ So, it becomes clear that trafficking involves three major stages which are recruitment, movement and destination. Let us now understand these stages briefly.

\section{Recruitment/ Origin}

Sites: People are recruited at many crowded places like railway stations or bus stops, cinema halls with other places like cafes, beauty parlours. The construction sites and state and national highways are also where people are recruited.

Time: Time is another major factor in their criminal game of trafficking. It is substantiated by some studies which mention that traffickers select special times for recruitment. They take advantage of difficult times either during the harvesting season or during a drought. Traffickers also kept themselves abreast with the deprived area.

Methods: Traffickers are adept in using skills and strategies ranging from persuasion to kidnapping. They sometimes drugged or abduct the victims and sometimes befriend and deceive them. Most commonly, they lure people with fake jobs and false marriages. People with low socio-economic status are offered dowry- free marriages and they fall into the trap of trafficking.

Players: Trafficking has involvement of many level players which consequently reinforce the organised trafficking. There is a wide nexus of police, administrative officials, railways and bus authorities or employees, taxi/auto rickshaw drivers or rickshaw pullers. They play different roles as investors or financiers, procurers or recruiters, document forgers, protectors or corrupt public officials, brothel operators, travel guides.

Types of operations: Trafficking happens through organised national networks, local trafficking rings or by occasional traffickers. They may act alone or in small groups.

\section{Movements/Transit}

Movement is all about transportation and routes of traffickers functioning. The general movement of trafficked people is from less developed areas to more developed region. Routes are generally divided into origin, transit and destination points. Some reports also mention routes as collection and dispersal points. In the Indian context, Nepal and Bangladesh are two main suppliers and the ease with traffickers move across the borders is an open secret. Once the women enter India, they are kept in West Bengal and Orissa. After being 'sorted out or graded' they may be sold to pimps or sent to the Middle East, Kolkata, Delhi, Mumbai and Agra. Studies conducted by ADB (2002) and Shamim (2001) list detailed trafficking routes in these areas.

\section{Destination}

Once they are brought to the destinations, the women may be 'sold' or transferred. In some cases, they are 'resold'. Now the question arises, what are their destinies? There are two major destination sectors which are commercial sexual exploitation and labour exploitation. In the commercial sexual exploitation, the women are pushed into prostitutions and sex tourism. In terms of labour exploitation, children are thrown into circus troupes, begging and domestic services. They are also large trafficked for adoption, organ transplant, marriage and debt bondage. This exposes the sort of Dickensian world of child labour and slavery spread all over the country.

\section{Trafficking in women and children in India}

Violence against women and children has crossed all limits in the present social scenario. Human trafficking is one of crime which not only dehumanizes women and children but also a shame for society. The rising cases (reported only) of procurement of minor girls, 53 per cent in 2013 according to NCRB speak volumes of the mess women and children are in. Assam, Bihar and West Bengal has witnessed the growing movement of traffickers and trafficking. In the case of women trafficking in India, sexual exploitation is the major purpose and the girls are put into prostitution. But these days, trafficking for bride has pricked our conscience. Girls are bought as brides from the states of Kerala and West Bengal and transported to Haryana, Punjab and parts of Uttar Pradesh and Rajasthan. Girls from the poor community are selected and targeted for this form of human trafficking. It is well known that these women are treated as sexual commodity and child- producing machines. The reason for this increased surge in bride trafficking is the complete skewed sex ratio of these states which purchase women and girls as brides. M. Shafiqur Rhaman Khan, who is a Delhi- based activist working on the issues of Human Rights, focusing on prevention of Human (bride) trafficking and honour-killing in India mentions in his piece of article that Panipat and Sonipat are the main transit points of the trade. A large number of "placement agencies" are working in this area to facilitate bride trafficking. Their main job is to bring the girls from the poverty-stricken states and supply in different parts of the state. A large number of people of Haryana works as truck drivers and also involve themselves simultaneously as network for procuring girls from the source area. This is one aspect of women trafficking where women from the poor areas are promised good job and marriage but sold for few bucks. There are many more situations like bar dancers of Mumbai where lives of thousands of women are at stake and caught in the web of trafficking.

Children are the major victims of human trafficking as they protest less and can be silenced easily. According to 2010 TIP report, there are 12.3 million adults and children are in forced labour, bonded labour and forced prostitution around the world, although many see this number as less representative of the problem. They claim it to be around 27 million which gives us the idea of the grave problem of human trafficking (Satyarthi, 2013). There are studies and strong evidences which establish that there are huge numbers of child labourers who are working in garment factories and other sectors across India. The children are easily lured away by the traffickers and brought to the destination point. All this is done by a complete network of placement agencies which supply these girls and children as domestic helps and garment factories. Also, children are trafficked as there is enormous demand for them. There are also instances of trafficking which goes with the practice of adoption and surrogacy. As the web of human trafficking traps any children, they pass on from one place to another place which is tantamount to re-victimization of the child again and again.

Child trafficking continues to be divided between ministries and departments. There is a lack of coordinated effort by the stakeholders. The point is that all the institutions concerned focuses majorly on postharm situation that is when children is already trafficked or harmed. There must be aims towards prevention. In their path-breaking study, Sen and $\mathrm{Nair}^{6}$ have also studied the various aspects of traffickers. Interestingly, thirty-nine percent of traffickers viewed trafficking as social evil while forty percent of them have said that it cannot be 
solved. This reflects the mentality of the traffickers and can be helpful in law framing.

\section{Role of the non-governmental organisations (NGOS)}

The report of the 'Trafficking in Women and children in India' by Sen and Nair ${ }^{6}$ presents a mixed picture of the NGOs. At one point of study of survivors of commercial sex exploitation, they were asked about the NGOs. Majority of them has appreciated the functionaries of the NGOs. But when the victims were asked to respond regarding the role of NGOs, a good number of victims were unaware of the NGOs engagement in the field of trafficking while few mentioned it's functioning in HIV prevention. In the present times, lot of NGOs are actively engaging themselves in the field of trafficking namely Human Rights Watch, Amnesty International, OXFAM, Save the Children, the Red Cross, Action Aid and Shakti Vahini. They have been indulging in social monitoring and advancing the knowledge of human rights.

\section{Trafficking and human rights}

The human rights discourse is profoundly silent on this grave issue which requires immediate attention and further deliberation. The Immoral Traffic Prevention Act, 1956 which was later amended in 1986 has not taken human rights of victims in its ambit. It also fell short on deterrent punishment leave alone the sensitive handling of rescue and rehabilitation of victims. Due to poor condition of rehabilitation homes and lack of medical and psychological support to traumatised victims, they become source for re-trafficking. ${ }^{14}$ Also, with the low-levels of poverty and high-levels of corruption, India has become the worst sufferer. Trafficking in humans is a serious affront to their dignity and human rights. It is a gross violation of victims' rights particularly all the basic fundamental rights like freedom and liberty, free speech and expression, education, right to life with dignity. It becomes a sordid tale of modern day slavery.

The brothels are the dens of violations of human rights. Women and children who have been trafficked and thereafter subjected to commercial sexual exploitation are "living embodiments of the ultimate violation of human rights". ${ }^{6}$ The survivors are the largely helpless souls of grim tale of trade. When the victims are arrested as accused, prosecuted and even convicted, the meaning of rights becomes absurd. What was meant to redress their grievances becomes tool of continuous victimization. This chilling tale of affairs calls for stern action by proper and effective use of the available legal provisions.

Trafficking has become an emotive issue about which much has written passionately rather than objectively because it touches the core of our beliefs about morality, justice, gender and human rights. It must be the priority area of the academia, legalists and the civil society. Human rights are the lifeline of any democratic society. It can never be loose talk. What is of urgent importance is that there should be equal emphasis on interpretation and change rather than latter taking over former.

\section{Combating human trafficking}

Mishra $^{13}$ has mentioned that any country largely has two approaches in combating human trafficking. These are:

Accused oriented: law and order problem: From very long time, human trafficking has been seen from a law and order perspective. It means that human trafficking problem can be tackled easily if law is fully implemented or policies are put in place. The central argument is that trafficking is legal problem and its perpetuation is because of poor law enforcement. Consequently, when the matter reaches the legal institutions, the traffickers are punished according to the suitable sanctions. So, here accused is the prime target and given huge consideration.

Victim oriented: human rights violation: This approach has many merits and essential to even our argument that human trafficking must be seen as human rights violation in the first place. The central thought of this approach is that victims should be of prime importance and must be given adequate attention. The concentration area must be the protection and rehabilitation of the victims.

\section{Conclusion}

Human rights embodied in the Indian Constitution are justifiable. All these rights now have the support of a large number of international conventions and human rights covenants dealing with human rights. Even the courts have used these international covenants to widen the scope of the human rights in the constitution of India. As a result, it is possible to judicially enforce a large number of human rights violations embodied in international covenants also. But the constitutional-cum-international mandate needs to be accompanied by correct social perceptions, support services and a basic change in family and societal values. A proper enforcement of these rights thus requires, educating people in these human rights so that these rights are respected and observed in practice. A soothing culture of human rights has to be developed in our country. National Human Right Commission has a greater role to play in dealing cases and need to recommend and take compensatory measures. People also need to aware about the commission and it is now for the people to take help of these available institutions in order to inculcate human rights values in the home, in the community, in the society and in the public. Also all the three pillars of the government i.e. legislature, executive and judiciary must now respect and promote this culture of human rights specially for the women, the weaker section of the society so that trafficking in women and children can be tackled in a greater extent. Even the NGOs, welfare agencies, legal experts, civil society and social workers have to play an important role to secure the rights of the women, child through advocacy, providing legal aids and legal education in the grass-root level to top. ${ }^{15}$

\section{Acknowledgements}

None.

\section{Conflict of interest}

Author declares there is no conflict of interest in publishing the article.

\section{References}

1. Ansari Hamid. Human Rights and Human Wrongs. Lecture delivered on 10th December 2013 at Vigyan Bhawan, New Delhi; 2013.

2. Madan G. Political theory and thought. Pargati, India; 2007.

3. Verma JS. Protecting Human Rights through Judicial Process. Lecture delivered on 21 December at Bhartiya Vidya Bhawan, India; 2002.

4. Upendra B. The future of human rights, 2nd ed. Oxford University Press, India; 2006. 
5. Amartya S. The idea of justice. The Belknap Press, USA; 2009. p. 462.

6. Sen S, Nair PM. A Report on trafficking on women and children in India 2002-2003 vol 1. Institute of Social Sciences, NHRC \& UNIFEM, India; 2004. p. 440.

7. Annie G, Vindhya U, Swamy R. Sex-trafficking and sex-work: definition, debates and dynamics- a review of literature. Economic and Political Weekly. 2010;45(17):64-73.

8. Human Rights Watch. Background briefing: International trafficking of Women HRW, USA; 2000.

9. International Labour Organisation. Stopping forced labour: global report under the follow-up to the ILO declaration on fundamental principles and rights at work. International Labour Office, Switzerland; 2001. p. 124

10. Allice B. Human Rights in Crisis. Ashgate, UK; 2008.
11. Bishwajit G. Trafficking in women and children in India: nature, dimensions and strategies for prevention. The international Journal of Human Rights. 2009;13(5):716-738.

12. Human Rights Watch. Trafficking of Nepali girls and women to India's brothels. HRW. 1995;12(5).

13. Veerendra M. Human trafficking- the stakeholders' perspective. Sage, India; 2013. p. 400.

14. Sujata M. Contemporary women's issues, marginalised women and human rights. Journal of the Human Rights Commission of India. $2013 ; 12: 1-13$

15. Mukherjee KK, Das D. Prostitution in metropolitan cities in India. Central Social Welfare Board, India; 1996. 